\title{
CORRESPONDENCE BETWEEN LEGISLATION AND PUBLIC OPINION IN BULGARIA ABOUT ACCESSTO ASSISTED REPRODUCTIVE TECHNOLOGIES (ART)
} SKLADNOST ZAKONODAJE Z JAVNIM MNENJEM V BOLGARIJI O DOSTOPU DO OPLODITVE Z BIOMEDICINSKO POMOČJO (ARTASSISTED REPRODUCTIVE TECHNOLOGIES)

\author{
Radoy Krastev', Vanyo Mitev ${ }^{1}$ \\ Prispelo: 16. 8. 2012 - Sprejeto: 18. 2. 2013
}

Original scientific article

UDC 618.177-089.888.11:343(043.2)

\begin{abstract}
Introduction: This is the first study on the correspondence between the legislation and public opinion in Bulgaria regarding access to assisted reproductive technologies (ART).

Methods: We carried out a national on-line-based cross-sectional survey in the Bulgarian language from July 2010 until June 2011. Participants were 951 respondents from 18 to 65 years of age who independently completed the anonymous survey. We were interested in: 1) Attitudes about a woman's age limit for ART, 2) the rate of acceptance of access of single women to ART, 3) the rate of approval of access of lesbian couples to ART, 4) the degree of acceptance of post-mortem assisted reproduction (PAR).

Results: Most of the respondents (54.9\%) approved of a woman's age limit of 43 years. The majority of the respondents (85.4\%) supported access of single women to ART, while $45.1 \%$ of the participants approved of lesbians using assisted reproductive technologies (ART). Approximately $71.7 \%$ of the respondents stated they would permit PAR.

Conclusions: People prefer 43 years as a woman's age limit for ART. The majority of the respondents accept access of single women to ART, but a two-fold lower percentage considers that lesbians should be allowed to use $A R T$. The majority of the respondents are proponents of PAR.
\end{abstract}

Key words: access to ART, surveys, Bulgaria, ethics, law

Izvirni znanstveni članek

\section{Izvleček}

UDK 618.177-089.888.11:343(043.2)

Namen: To je prva študija o skladnosti zakonodaje z javnim mnenjem v Bolgariji o dostopu do oploditve z biomedicinsko pomočjo (ART).

Metode: V obdobju od julija 2010 do junija 2011 smo izvajali nacionalno spletno presečno anketo $v$ bolgarščini. V anketi je sodelovalo 951 anketirancev, starih od 18 do 65 let, ki so samostojno izpolnili anonimno anketo. Zanimalo nas je sledeče: 1) Stališče o starostni meji za ženske za ART; 2) Stopnja odobravanja dostopa do ART za samske ženske; 3) Stopnja odobravanja dostopa do ART za lezbične pare; 4) Stopnja odobravanja posmrtne oploditve z biomedicinsko pomočjo (par-postmortem assisted reproduction).

Rezultati: Večina anketirancev (54,9\%) se je strinjala s starostno mejo 43 let za ženske. Večina anketirancev $(85,4 \%)$ je odobravala dostop do ART za samske ženske, medtem ko se je s tem, da lezbijke uporabljajo postopke oploditve z biomedicinsko pomočjo (ART) strinjalo 45,1 \% anketirancev. Približno 71,7\% posameznikov je navedlo, da bi dovolili PAR.

Zaključek: Ljudje so naklonjeni starostni meji 43 let za ženske za ART. Večina anketirancev odobrava dostop do 
ART za samske ženske, vendar pa je odstotek anketirancev, ki menijo, da lahko lezbijke uporabijo postopke ART dvakrat nižji. Večina anketirancev zagovarja PAR.

Ključne besede: dostop do ART, vprašalniki, Bolgarija, etika, zakonodaja

\section{INTRODUCTION}

Countries around the world have responded to the emergence of assisted reproductive technologies (ART) in a variety of ways. Some countries prohibit certain treatment, others support them through health insurance, while other countries permit them but do not help pay for them. Because of these differences, not all people have the same degree of access to ART. In May 2010, a 62 year-old woman gave birth to twins using IVF in Bulgaria. In the same year, a 43 year old woman lodged a complaint, and in June 2011, the Supreme Administrative Court of Bulgaria ruled that the age limits for access to ART as fixed in the regulations are discrimination and are against the Bulgarian constitution and the Protection Against Discrimination Act.

After this decision, the regulations in Bulgaria changed and now access to ART for all women of fertile age is allowed. Single women and homosexual female couples (in Bulgaria the notion of "lesbian marriage" does not exist) have access to ART through donor sperm banks. However, women over 45 years of age as well as single and lesbian women have little chance of receiving reimbursement from the Bulgarian Fund for ART.

Posthumous Assisted reproduction (PAR) is prohibited in Bulgaria in spite of previously given informed consent of the husband, the partner or the donor.

According to some authors (1) the EU's Tissues and Cells Directive /2004/ was created to harmonize Assisted Reproductive Technologies (ART) regulations in the EU. Nevertheless, there are many differences between the legislations of the member states in regard to access to ART. The differences concern women's age limit and access of single women and lesbians to ART and PAR.

Nine of the 27 member states of the EU legally determine the maximum age for women for access to ART, which varies from 40 years in Finland to 50 years in Greece, the Netherlands and Estonia. In 6 member states (France, Czech Republic, Germany, Portugal, Sweden and Bulgaria), the age restrictions in the legislation are linked with the natural reproductive age of the woman. In the United Kingdom and Spain, there is no legal age limit, but there is a strictly determined age for the reimbursement of the expenses. In the remaining member states of the EU, there are no legal age limits for access to ART (2).
In some US states, the women's age limits are related with the reimbursement of the expenses for ART. For example, in Connecticut and Rhode Island -40 years, in New Jersey - 45 years and in New York - 44 years (3). Usually the ART are considered as therapeutic tools for the treatment of infertility. In the case of single women and lesbian couples, social functions are attributed to ART (4). These are healthy women who cannot or do not want to find a permanent male partner but wish to have children while they are still of fertile age (5).

In regard to marital status, ART is reserved only for married or permanently living together heterosexual couples in 6 of the 27 member states of the EU (2). In 9 countries, the law allows ART for single women. In 4 member states (Sweden, United Kingdom. Spain and Finland), the law permits ART for homosexual female couples as well as for single women. (6).

In 14 states of the USA, the practice of reimbursement of the expenses for ART is allowed only for heterosexual married couples. Therefore, the access of single women and homosexual female or male couples and transgender couples to ART is restricted (3).

The transfer of frozen gametes or embryos after the death of a parent or donor is an ethical question, and on one side it is in the interest of the surviving partner and on the other side it is in the interest of the child to have a living father and mother.

PAR is prohibited in 11 member states of the EU and in the other 16 member states it is allowed. There are legal restrictions in 7 of them. In Belgium, the Netherlands, Spain and the United Kingdom, a written consent of the deceased is necessary; in Hungary, the ART process must have started before the partner died, and in Greece posthumous insemination can be done only after a court decision. There are time limits in some countries. Posthumous insemination must be started after 6 months in Belgium and Greece and must be completed within one year in Spain, 2 years in Greece and the Netherlands and within 3 years in Belgium (6). Only in Spain (7) do these children have a portion in the forced succession.

In some states of the USA, a written consent of the deceased for the creation of children after his/ her death is required (6). Only eleven states have attempted to address by statute the inheritance rights of posthumously conceived children (8). 
This current documentrelatesa study of public opinion in Bulgaria about access to assisted reproductive technologies (ART). The investigation was performed by an online survey.

\subsection{Objectives}

1.Correspondence between the legislation and public opinion in Bulgaria regardingaccess to ART;

2. Influence of demographic characteristics on the answers of the respondents

\section{MATERIALS AND METHODS}

\subsection{Participants}

The on-line survey was carried out in cooperation with the company "Kupisait", a provider of on-line survey software and corresponding resources. The survey was installed on a specially created for this purpose web-site www.bioetika.org on which a lot of additional information about ART was presented together with a forum for discussion. The web-site was accessible in the Bulgarian language from July 2010 until June 2011. Cookies were set in order to prevent multiple responses from one person.

Our study is directed towards Bulgarian people of working age - from 18 to 65 years. Considering the specificity of the questions, we preferred to obtain answers from younger persons - from 18 to 43 years of age and people with infertility problems. That is why www.bioetika.org had been advertised on university web-sites and on www.bg-mamma.com and www. zachatie.org, which are visited by people with infertility problems.

Eligibility criteria about the respondents: female and male individuals from 18 to 65 years old who have answered all the questions in the survey.

\subsection{Materials}

There are four questions about access to ART and five demographical questions concerning sex, age, education, marital status and place of residence.

Question 1-ART may be performed on women:

$$
\begin{aligned}
& a \text { - up to } 43 \text { years } \\
& a \text { - up to } 53 \text { years } \\
& a \text { - up to } 63 \text { years } \\
& a \text { - without age limit }
\end{aligned}
$$

The reasons to choose these age limits are the following:

43 years was the age limit in the Bulgarian legislation at the time of the survey;
53 years was the proposed age limit by the associations of women with fertility problems;

63 years due to the event mentioned in the introduction; Without age limit for those who consider that access to ART should not be restricted by age limit.

Question 2 - Should the law allow ART for single unmarried women?

Question 3 - Should the law allow ART for homosexual female couples with the use of a sperm donor?

Question 4 - Should the legislation allow for artificial insemination with the sperm of adead husband or the transfer of a frozen embryo after the death of one of the parents?

The possible answers to questions 2, 3 and 4 are yes, no and I cannot answer.

That is why all the respondents were classified into three groups: those who "approved", "disapproved" or were "undecided". The answers of questions 1, 2, 3 and 4 are presented in diagrams of the Bar-Chart for better visualization.

\subsection{Statistics}

The answers to the questions were encoded and were converted into CSV files for further statistical analysis. The data were treated with statistical package SPSS 16. The determination of the link between the demographic characteristics and the answers of the respondents was made using the $\square^{2}-$ method of Pearson Chi-Square in cross tables $2 \times 2$, the Linear by Linear Association in cross tables $2 \times \mathrm{K}$, cross-tabulation, graphical analysis - diagrams of Bar-Chart and the one factor dispersion analysis of Kruskal -Wallis. The critical level of significance was 0.05 . The zero hypothesis is rejected when $\mathrm{p}<0.05$.

\section{RESULTS}

The survey was completed by 994 respondents. Finally, 951 respondents remained after the removal of respondents under 18 and above 65 years of age and those who had not answered all the questions.

The age limit of 43 years was considered as the most appropriate by $54.9 \%$ of the respondents, $33.2 \%$ proposed this age limit to be 53 years, $0.6 \%$ accepted 63 years and $11.3 \%$ thought access to ART should be without an age limit (Figure 1).

The second question is about the access of single women to ART. The great majority of the respondents (85.4\%) supported access of single women to ART. Only $9.5 \%$ were against the access and $5.1 \%$ could not answer (Figure 2A). 


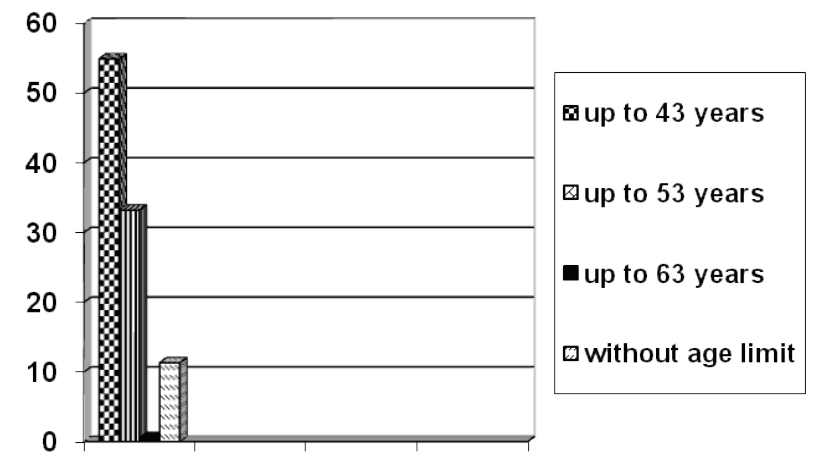

Figure1. Woman's age limit for $A R T$ (\%).

Slika 1. Starostna meja za ženske za ART (\%).

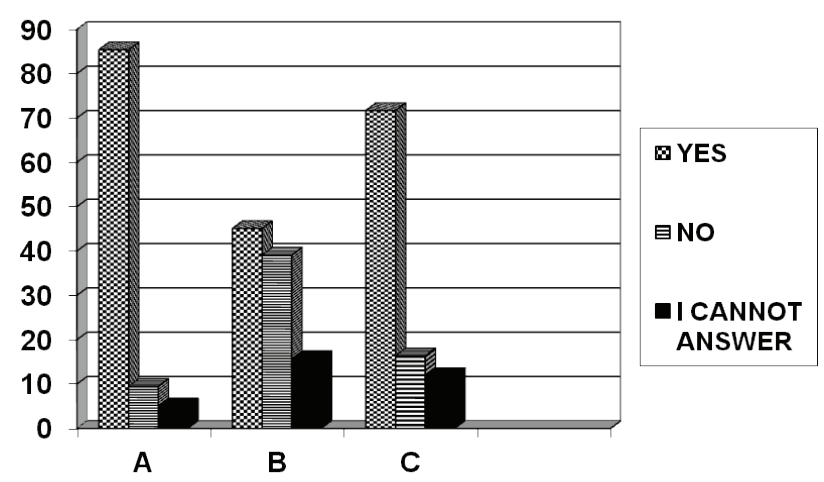

Figure 2. Attitudes towards legislation concerning:

A - Access of single women to ART (\%)

B - Access of lesbian couples to ART (\%)

$\mathrm{C}$ - Posthumous reproduction (\%)

Slika 2. Odnos do zakonodaje $v$ zvezi z:

A - Dostopom do ART za samske ženske (\%)

B - Dostop do ART za lezbične pare (\%)

C - Posmrtna oploditev (\%)

The third question is about the access of homosexual female couples to ART. Less than half of the respondents $(45.1 \%)$ agreed that lesbian couples shouldhave their own child using ART. $39.1 \%$ were opposed and $15.8 \%$ could not answer (Figure 2B).

The fourth question was referring to posthumous reproduction with the semen of adead husband or about the transfer of afrozen embryo after the death of one of the parents. Most of the respondents $(71.7 \%)$ supported PAR, only $16.4 \%$ opposed and $11.9 \%$ could not answer (Figure 2C).
Table 1. Demographic characteristics of the respondents (\%).

Tabela 1. Demografske značilnosti anketirancev (\%).

\begin{tabular}{|c|c|c|}
\hline \multicolumn{2}{|c|}{$\begin{array}{l}\text { Demographic characteristic/ } \\
\text { Demografska značilnost }\end{array}$} & $\%$ \\
\hline \multirow{2}{*}{$\begin{array}{l}\text { Sex/ } \\
\text { Spol }\end{array}$} & Men/Moški & 21.1 \\
\hline & Women/Ženske & 78.9 \\
\hline \multirow{4}{*}{$\begin{array}{l}\text { Age/ } \\
\text { /years/ } \\
\text { Starost /let/ }\end{array}$} & $18-35$ & 62.6 \\
\hline & $36-43$ & 24.8 \\
\hline & $44-51$ & 8.2 \\
\hline & $52-65$ & 4.4 \\
\hline \multirow{3}{*}{$\begin{array}{l}\text { Education/ } \\
\text { Izobrazba }\end{array}$} & Secondary/ Srednješolska & 37.6 \\
\hline & University/Univerzitetna & 46.8 \\
\hline & $\begin{array}{l}\text { Medical University/ } \\
\text { Univerzitetna s področja } \\
\text { medicine }\end{array}$ & 15.6 \\
\hline \multirow{5}{*}{$\begin{array}{l}\text { Marital } \\
\text { Status/ } \\
\text { Zakonski stan }\end{array}$} & Unmarried/Neporočen & 36.4 \\
\hline & Married/Poročen & 43.7 \\
\hline & Divorced/Ločen & 3.9 \\
\hline & $\begin{array}{l}\text { Widow/widower/Vdovec, } \\
\text { vdova }\end{array}$ & 1.3 \\
\hline & $\begin{array}{l}\text { Living with partner/ V } \\
\text { zunajzakonski zvezi }\end{array}$ & 14.7 \\
\hline \multirow{2}{*}{$\begin{array}{l}\text { Place of } \\
\text { Residence/ } \\
\text { Kraj prebivanja }\end{array}$} & Capital/Glavno mesto & 47.1 \\
\hline & Country/Podeželje & 52.9 \\
\hline
\end{tabular}

The demographic characteristics of the respondents are given in Table 1. The percentage of women is almost 4 times higher than that of men $(78.9 \%$ against $21.1 \%$ respectively). The majority of the respondents $(87.4 \%)$ were young people from 18 to 43 years old. Persons with a university education and medical university education more readily answered the survey $(46.8 \%$ and $15.6 \%$ respectively). The dominating groups in regard to marital status were those married $(43.7 \%)$ and singles (36.4\%). The distribution of the respondents is the following $47.1 \%$ in the capital and $52.9 \%$ in the rest of the country. Table 2 shows that sex has statistical significance in regard to the answers to the questions about age limit to ART, the access of single women to ART and posthumous reproduction $(p<0.05)$. The age of the respondents determines a significant difference in regard to age limit and lesbian access to ART. Marital status gives a statistically significant difference to answers to all questions, while the place of residence has no statistical importance. 
Table 2. Statistical significance of demographic characteristics on the answers.

Tabela 2. Statistična pomembnost demografske značilnosti za odgovore.

\begin{tabular}{|c|c|c|c|c|}
\hline \multirow{2}{*}{$\begin{array}{l}\text { Demographic } \\
\text { characteristic/ } \\
\text { Demografska } \\
\text { značilnost }\end{array}$} & $\begin{array}{l}\text { First question/Prvo } \\
\text { vprašanje }\end{array}$ & \begin{tabular}{|l} 
Second question/ \\
Drugo vprašanje
\end{tabular} & $\begin{array}{l}\text { Third question/ } \\
\text { Tretje vprašanje }\end{array}$ & $\begin{array}{l}\text { Fourth question/ } \\
\text { Četrto vprašanje }\end{array}$ \\
\hline & P-value/P-vrednost & $\begin{array}{l}\text { P-value/ P- } \\
\text { vrednost }\end{array}$ & $\begin{array}{l}\text { P-value/ P- } \\
\text { vrednost }\end{array}$ & $\begin{array}{l}\text { P-value/ P- } \\
\text { vrednost }\end{array}$ \\
\hline Sex/Spol & $0.0001^{*}$ & $0.0001^{*}$ & 0.542 & $0.031^{*}$ \\
\hline Age/Starost & $0.0001^{* *}$ & 0.213 & $0.023^{*}$ & 0.371 \\
\hline $\begin{array}{l}\text { Education/ } \\
\text { Izobrazba }\end{array}$ & $0.0001 * *$ & 0.333 & 0.240 & 0.209 \\
\hline $\begin{array}{l}\text { Marital status/ } \\
\text { Zakonski stan }\end{array}$ & $0.0001 * *$ & $0.012^{* *}$ & $0.005^{* *}$ & $0.008^{* \star}$ \\
\hline $\begin{array}{l}\text { Place of residence/ } \\
\text { Kraj prebivanja }\end{array}$ & 0.139 & 0.769 & 0.103 & 0.115 \\
\hline
\end{tabular}

For example, $72.2 \%$ of the men consider that the women's age limit of 43 years is the best for ART, while only $50.5 \%$ of the women have the same opinion. The age of the respondents influences the answers to question 1 about the age limit for ART. The youngest (18-35) and the oldest (52-65) respondents are proponents of the age limit of 43 years $(62 \%$ and $61.9 \%$ respectively). The same age limit is firmly supported by people with a secondary school education (69.7\%) or medical university education $(60.0 \%)$, while only $41.3 \%$ of the respondents with a non-medical university education have the same opinion.

Younger persons are also more tolerant about the access of lesbian couples to ART.

Marital status influences the answers to all questions. For example, $58.4 \%$ of the respondents living with a partner and only $9.1 \%$ of widowers agree with the access of lesbian couples to ART.

\section{DISCUSSION}

The number of the women is several times higher than that of men as shown by the results of the demographic characteristics of the respondents as given in Table 1.A possible explanation can be the dominating conviction in Bulgaria that the problems of reproduction and infertility are concerning mainly women.

Our results show that $54.9 \%$ of the respondents consider the women's age limit of 43 years as the most appropriate for ART. Another $33.2 \%$ accept 53 years as the age limit. Very few $(0.6 \%)$ are convinced that this limit should be 63 years, and $11.3 \%$ think that access to ART should be without an age limit (Fig.1). The women's age limit of 43 years is mainly supported by men $(72.2 \%)$, by the youngest $(62 \%)$ and the oldest $(61.9 \%)$ respondents, by people with a secondary school education (69.7\%) and by the unmarried $(71.9 \%)$.

Our results are similar to the survey made by the BBVA Foundations (9) in 15 countries (12 of them European). ART for women above 45 years is rejected in 12 countries, with the highest degree of rejection in Denmark, Germany, Austria, France and the Netherlands. ART for women above 45 years is accepted in Israel, Japan and Spain.

Some authors recommend the freezing of ova of healthy women below 40 in order to proceed with later ART (10). So-called "social ova freezing" is proposed to be reimbursed by health insurance (11).

During 2006-2007, a European survey concerning the social age deadline for childbearing in women and men was made (12). The majority (96.4\%) of the European respondents indicated a maternal age deadline of 41.7 years and the respondents from Bulgaria -41.2 years, which is quite similar to our results (43 years).

The ESHRE//European Society of Human Reproduction and Embryology/ Task Force for ethics and law 14 underlines that the age limit for ART must not be absolute, because the justice impose all factors that concern the percentage of success rate to be taken into consideration, including the ovarian reserve(13). 
Most of the 951 respondents (85.5\%) in our survey are proponents of the access of single women to ART, only $9.5 \%$ are opponents and $5.1 \%$ cannot answer (figure 2A). The most in favour are women (89.4\%) and respondents living with a partner (92.1\%).

In regard to the third question, less than half of the respondents $(45.1 \%)$ support the access of lesbian couples to ART, $39.1 \%$ have the opposite position and $15.7 \%$ cannot answer (figure 2B). Here, the supporters are mainly younger respondents $(46.4 \%)$ and those living with a partner (58.4\%). Bulgarian law does not make any difference between single women and lesbian couples, and all women who do not have a permanent male partner can have access to ART with donor semen. In the survey made by the BBVA Foundations (9), the access of single women to ART is accepted only in 7 of 15 countries. The highest approval for single women's access to ART is in the Czech Republic, Spain and Israel and the lowest in Austria, Italy, the United Kingdom and Japan. With the exception of Denmark, the Netherlands and Spain, average acceptance of the use of semen banks by lesbian couples is below $50 \%$ in all countries and is similar to our results.

A survey in Australia explored the attitudes to access to ART for single women and for lesbians; $38 \%$ of respondents approved of access for single women and $31 \%$ of respondents approved of access for lesbians (14). The study of Brazilian authors shows that female and young male professionals working with ART are more tolerant and inclined to perform insemination of single women with donor semen (15).

In a survey among health practitioners that was carried out in Denmark, the approval of access to ART was $42 \%$ for single women and $37.4 \%$ for lesbians (16). In our survey, the answers of health practitioners are for the access of single women to ART $-83.6 \%$ and for the access of lesbians to ART $-47.1 \%$ respectively.

Some physicians refused ART to single women and lesbian couples considering that ART must be applied only for the treatment of infertility of married heterosexual couples and in connection with the breeding of future children. They think that the children need a normal family with a father and mother (17). According to others, the allowance of ART for single women and lesbian couples will additionally weaken the stability of the marriage, will break down the family unit and will depreciate men (18).

There are investigations that show no difference in the physical and psychological development of children that grow up in the presence or absence of a father $(19,20)$. Concerning question four, $71.7 \%$ of 951 respondents stated they accepted PAR, only $16.4 \%$ rejected PAR and $11.9 \%$ cannot answer (figure $2 \mathrm{C}$ ). The highest degree of acceptance was demonstrated by the female respondents (74.3\%) and by the divorced (80.6\%). A Japanese study of views among students on posthumous reproduction found that about $60 \%$ of respondents agreed with posthumous reproduction (21). Similar results were obtained at the University fertility clinic in New York where 106 couples completed an anonymous survey independently of their partner. Approximately $78 \%$ of the individuals stated that they approved of PAR (22).

Some authors are in favour of PAR when the deceased has left frozen semen (23-25).

According to $(23,24)$, for the realization of posthumous reproduction, the following three conditions are necessary: written consent given by the deceased; counselling of the surviving partner during the decision making period; a minimum waiting period of 1 year after the death should be imposed before the treatment can be started.

Some authors consider that the refusal of a reproductive centre to perform a posthumous insemination if the centre keeps frozen sperm from the deceased is a violation of article 8 of the European Convention on Human Rights (basic right to family) (25).

Sometimes, the relatives of the deceased have different wishes about the use of the frozen semen (26). It is proposed that the law should respect the wishes of the wife.

The transfer of a frozen embryo is mostly accepted when the surviving spouse is a woman. In the opposite case, the surviving husband must use a surrogate mother, which can create complications (23). ESHRE recommends that no difference should be made, and that the transfer of a frozen embryo be allowed regardless of the sex of the surviving spouse (24).

There are opponents of PAR. The right of the child to have living parents always has priority during debates in France (27). The same arguments are used by Landau (28), when she criticizes the guidelines of the Israeli government for posthumous reproduction, referring to Paragraph 3 of the UN Convention on the Rights of the Child (UN General assembly, 1989), which explicitly states that in all issues involving children the rights of the child have priority over other interests.

Others consider that children born as a result of posthumous reproduction will not differ from children bred by single women, where it is established that the psychological effect is minimal (23).

PAR is forbidden in Bulgaria. The associations of women with fertility problems have participated actively in our study and have the intention of organizing a discussion about PAR as well as about reimbursement of ART for single women and lesbians. 
A limitation of our study is that it is restricted to Bulgaria and is based on the answers of individuals from 18 to 65 years old. The political and cultural factors in the different countries influence the policies and opinions on ART. Therefore, one should be careful when generalizing our findings beyond Bulgaria.

\section{CONCLUSIONS}

- Priority in regard to the age limit for ART is given to women younger than 43 years, which corresponds to the existing regulations at the time of the survey;

- The majority of the respondents accept the access of single women to ART with the use of a semen donor;

- Less than half of the respondents consider that lesbian couples have the right to become mothers using ART;

- The majority of the respondents are proponents of posthumous insemination as well as to the transfer of frozen embryos after the death of one of the parents, contrary to the existing legislation.

\section{Funding}

This work was supported by grant D17/2010 of the Medical University of Sofia, Bulgaria.

\section{References}

1. Sorensen C. ART in European Union. Euro Observer 2006; 8: 1-4.

2. Final Report ESHRE 2008 - Comparative analysis of medically assisted reproduction in the EU: regulation and technologies/ SANCO/2008/C6/051. Accessed December 2008 at:

http://ec.europa.eu/health/blood_tissues_organs/docs/study_ eshre_en.pdf.

3. Arons J. Future choices, assisted reproductive technologies and the law. Accessed December 2007 at: http:/ www. americanprogress.org.

4. CECOS - Contribution de la Federation Francaise des Centres d'etude et de conservation des oeufs et du sperme humain - Fevrier 2009. Accessed February 2009 at : http:/www. etatsgenerauxdelabioethique.fr.

5. Frederiksen ME, Christensen U, Tjornhoj-Thomsen T, Schmidt L. Solo mother by donor-the plan B of motherhood: a perspective on person-centered reproductive medicine. Int J Person Centered Med 2011; 1: 800-807.

6. Surveillance 2010: preface. International Federation of Fertility Societies. Accessed September 14, 2010 at:

External link http:/www.iffs-reproduction.org/IFFS_ Surveillance_2010.

7. Delgado JJI. Inheritance rights for the child born from post mortem fertilization. Rev Derecho Genoma Hum 2008; 29: 13-31.

8. Lewis, Browne C. Graveside birthday parties: the legal consequences of forming families posthumously. Case Western Reserve Law Rev 2010; 60; 1159-1182.
9. Fundacion BBVA attitudes towards assisted reproduction and preimplantation genetic. Diagnosis. Science Daily. Accessed December 17, 2008 at: http://www.sciencedaily.com/releases/2008/12/081217101440.htm.

10. Stoop D, Nekkebroeck J, Devroey P. A survey on the intentions and attitudes towards oocyte cryopreservation for non-medical reasons among women of reproductive age. Hum Reprod 2011; 26: 655-661.

11. Mertes $\mathrm{H}$, Pennings $\mathrm{G}$. Elective oocyte cryopreservation: who should pay? Hum Reprod 2012; 27: 9-13.

12. Billari FC, Goisis A, Liefbroer AC, Settersten RA, Aassve A, Hagestad G, Speder Z. Social age deadlines for the childbearing of women and men. Hum Reprod 2011; 26: 616 - 622.

13. Pennings G, De Wert G, Shenfield F, Cohen J. Tarlatzis B, Devroey P. ESHRE Task force on ethics and law 14: equity of access to assisted reproductive technology. Hum Reprod 2008; 23: 772-774.

14. Kovacs GT, Morgan G, Wood EC, Forbes C, Howlett D. Community attitudes to assisted reproductive technology: a 20year trend, MJA 2003; 179: 536-538.

15. Zachia S, Knautch D, Goldim JR, Chachamovich JR, Chachamovich E, Paz AH, Felberbaum R, Crosignani PG, Tarlatzis BC, Passos EP. Assisted reproduction: what factors interfere in the professional's decisions?: are single women an issue? BMC Women's Health 2011: 11-21. Available at: http:/ www.biomedcentral.com/1472-6874/11/21.

16. Fonnest IF, Sondergaard F, Fonnest G, Vedsted-Jacobsen A. Attitudes among health care professionals on the ethics of assisted reproductive technologies and legal abortion. Acta Obstet Gynecol Scand 2000; 79: 49-53.

17. The Ethics Committee of American Society for Reproductive Medicine Access to fertility treatment by gays, lesbians, and unmarried persons. Fertil Steril 2009; 92: 1190-1193.

18. Rogers D. Unattainable joy: unequal access to assisted reproductive technologies. Accessed June, 2010 at: http://www. writing.ucsb.edu/50awards/2011_Awards/Rogers.

19. Weissenberg R, Landau R, Madgar I. Older single mothers assisted by sperm donation and their children. Hum Reprod 2007; 22: 2784-2791.

20. Rank N. Barriers for access to assisted reproductive technologies by lesbian women: the search for parity within the healthcare system. Hous J Health Law Policy 2010; 10: 115-146.

21. Ueda N, Kushi N, Nakatsuka M, Ogawa T, Nakanishi $\mathrm{Y}$, Shishido K, Awaya T. Study of views on posthumous reproduction, focusing on its relation with views on family and religion in modern Japan. Acta Med Okayama, 2008.

22. Nakhuda GS, Wang JG, Sauer MV. Posthumous assisted reproduction: a survey of attitudes of couples seeking fertility treatment and the degree of agreement between intimate partners. Fertil Steril 2011; 96: 1463-1466.

23. Bahadur G. Opinion death and conception. Hum Reprod 2002; 17: 2769-2775.

24. Pennings G, De Wert G, Shenfield F, Cohen J, Devroey P, Tarlatzis B. .ESHRE task force on ethics and law 11: posthumous assisted reproduction. Hum Reprod 2006; 21: 3050-3053.

25. Kruger M. The prohibition of post-mortem-fertilization, legal situation in Germany and European Convention on human rights. Revue Int Droit Penal 2011; 82: 41-64.

26. Chatzinikolaou N. The ethics of assisted reproduction. J Reprod Immunol 2010; 85: 3-8.

27. Le Coz P. Respecter l'embryon humain? In: Lois de bioethique: reexamen, enjeux et debats. Paris: La documentation Francaise, 2009; 49-61.

28. Landau R. Posthumous sperm retrieval for the purpose of later insemination or IVF in Israel: an ethical and psychosocial critique. Hum Reprod 2004; 19: 1952- 1956. 